\title{
Role of Serum Alanine Aminotransferase Aspartate Aminotransferase and Alkaline Phosphatase in Early Detection of Protein Energy Malnutrition
}

\author{
Karmacharya $\mathrm{K}^{1}$, Islam $\mathbf{M N}^{2}$ \\ ${ }^{1}$ Dr. Kalpana Karmacharya, MD Paediatrics. ${ }^{2}$ Prof. Dr. MN Islam MD Paediatrics, Department of Pediatrics, Bangbandhu Seikh \\ Mujib Medical University, Dhaka, Bangladesh.
}

Address for Correspondence: Dr. K Karmacharya, E-mail: kalpana17@hotmail.com

\begin{abstract}
Objective: Although Protein Energy Malnutrition (PEM) has been studied extensively; the best criteria for its detection in early stages have not been established. This study was carried out to observe the change in transaminases, alkaline phosphatase levels when compared with control and also to see their relationships with various grades of PEM. Then to see if certain biochemical parameters could be used to detect malnutrition in early stage. Methods: Cross sectional study between Jan 1999-Dec 2000,124 children from 5 months to 5 years were included in the study. Out of 124 children 98 (79\%) were cases and 26 (21\%) normal age matched healthy controls. Cases were divided into groups as per Gomez classification (Group1-Grade I PEM, 37;Group 2- Grade II PEM, 34; Group 3- Grade III PEM27; and Group 426 Healthy controls). Three serum enzymes, Alanine aminotransferase (ALT), Aspartate aminotransferase (AST) and Alkaline Phosphatase (ALP) was analyzed and for statistical analysis student's " $t$ " test was used. Results: The mean serum values +SD of ALT (Grade I PEM-41.40 +13.25,Grade II PEM-31.53+10.6,GradeIIIPEM-33.77+12.45,Control-23.11+8.73) and Aspartate aminotransferase (Grade I PEM-42.8+11.06,Grade II PEM 31.47+8.32,GradeIII PEM 35.00+10.86, Control-25.42+8.77) in patients with PEM were significantly $(\mathrm{p}<.0 .001)$ higher than controls. The degree of increase in serum values of these two enzymes was maximum in cases with Grade I PEM. The mean serum values of Alkaline phosphatase (Grade I PEM-403.40+100.76, Grade II PEM-294.23+50.40,Grade III PEM-221.26+94.09, Control-894.5+ 126.28) in cases of PEM were significantly lower than controls, lowering being maximum in PEM Grade III. Conclusion: It can be concluded that abnormalities in blood levels of these enzymes occur in any form of PEM and these are related to the severity of the disease. Hence this may be helpful in early diagnosis of PEM where clinical features are equivocal.
\end{abstract}

Key words: Protein Energy Malnutrition, Enzymes, Alanine Aminotransferase, Aspartate aminotransferase, Alkaline phosphatase

\section{Introduction}

In spite of the many advances in medicine and technology, malnut rition is still common. One quarter of the third world population suffers from malnutrition ${ }^{1}$. Malnutrition is estimated to be a contributory factor in 30$50 \%$ of all childhood deaths ${ }^{2}$ PEM is known to be associated with many biochemical disturbances in the body. Enzymes being proteins, disturbances in their functions and levels in the body are expected to occur in PEM of any severity ${ }^{3}$. Therefore measurement of these enzymes can thus provide the physician with valuable diagnostic and prognostic clinical evidence. This study was undertaken to see enzyme change and their relationship with control and various Grades of PEM. It also aims to see if any biochemical parameters could be helpful in early diagnosis of PEM.

\section{Methods and Materials}

A total of 124 (98 cases and 26 controls) from 5 months to 5 years attending out patient department and those who were hospitalized at BSMMU (Bangbandhu Seikh Mujib Medical University), BICH (Bangladesh Institute of Child Health) were studied. Among them 29 children were from slum area (Agargoan Basti) and 26 were age and sex matched healthy controls with normal nutritional status (wt/age $>90 \%$ of NCHS Median). The subjects were classified as per Gomez classification $^{4}$.

Group1-GradeI PEM ( $\mathrm{n}=37)$

Group 2- Grade II PEM ( $\mathrm{n}=34)$

Group 3 Grade III PEM $(\mathrm{n}=27)$

Group 4 Controls $(n=26)$

The exclusion criteria was children suffering from any systemic disease other than PEM, but minor association like diarrhoea, cough and cold was included in the study. After taking the consent from mothers and guardians they were put through a pre-coded questionnaire to collect data related to the study. Then $3 \mathrm{ml}$ of blood was drawn and serum was separated by centrifuge machine at $3000 \mathrm{rpm}$ for $5 \mathrm{~min}$. Estimation of enzyme was carried out as soon as possible. Whenever there was delay in estimation, samples were stored in refrigerator at $-350 \mathrm{C}$.

Biochemical Analysis: Serum ALT and AST was determined by kinetic ultraviolet method according to 
the recommendation of the expectances of international Federation of clinical chemistry IFCC (Bergemeyer, Bowers $\&$ Close 1976). Serum ALP was determined by optimal standard method according to the recommendation of German clinical Chemistry Association (GCCA). For statistical analysis student's " $t$ " test was used.

\section{Results and Observations}

In the study group 37\% were Grade I PEM, 35\% Grade II PEM and 28\% Grade III PEM.

Fig 1: Number of Children in Different Grades of PEM

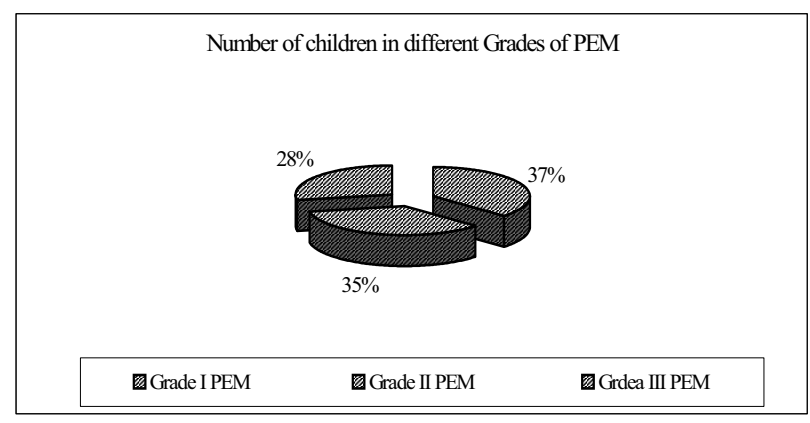

Table I: Age and Sex Distribution of Cases $(n=98)$

\begin{tabular}{|l|c|c|c|c|c|c|}
\hline $\begin{array}{l}\text { Age } \\
\text { group }\end{array}$ & \multicolumn{4}{|c|}{ Sex } & \multicolumn{3}{c|}{ Total } \\
\hline & \multicolumn{2}{|c|}{ Male } & \multicolumn{2}{c|}{ Female } & \multicolumn{2}{c|}{} \\
\hline & $\mathrm{n}$ & $\%$ & $\mathrm{n}$ & $\%$ & $\mathrm{n}$ & $\%$ \\
\hline$<1 \mathrm{yrs}$ & 22 & 61.1 & 14 & 38.9 & 36 & 100.0 \\
\hline 1yrs-3yrs & 29 & 64.4 & 16 & 35.6 & 45 & 100.0 \\
\hline 3yrs-5yrs & 13 & 76.5 & 4 & 23.5 & 17 & 100.0 \\
\hline Total & 64 & 65.3 & 34 & 34.7 & 98 & 100.0 \\
\hline
\end{tabular}

Among them 36 were below one year, 45 cases were between 1-3yrs and 17 cases were between 3-5yrs.

Fig 2: Age Distribution of Cases in Years

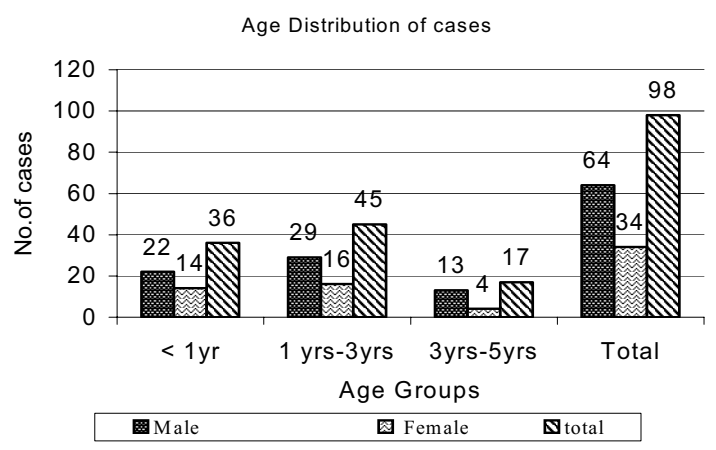

\section{Alanine Aminotransferase}

The mean values of transaminases (ALT\&AST) levels were significantly higher in all Grades of PEM than controls, shown in table II and table III respectively. The levels decreased with increasing Grades of PEM but Grade III PEM had higher level of ALT \& AST than Grade II PEM, shown in Table II. 't' values and probabilities between different grades of PEM for ALT and AST levels are shown in table IV and table $\mathrm{V}$ respectively.

Table II: Mean + SD, T Values \& P Values Between Different Grades Of PEM and Control for Serum ALT Levels

\begin{tabular}{|l|c|c|c|c|}
\hline Groups & $\begin{array}{c}\text { Serum ALT } \\
\text { mean } \pm \text { SD }\end{array}$ & d.f. & 't' values & 'p' values \\
\hline Grade I & $41.40 \pm 13.25$ & 61 & 6.60 & $<0.001$ \\
\hline Grade II & $31.53 \pm 10.6$ & 58 & 3.71 & $<0.01$ \\
\hline Grade III & $33.77 \pm 12.45$ & 51 & 3.62 & $<0.001$ \\
\hline Control & $23.11 \pm 8.73$ & - & - & - \\
\hline
\end{tabular}

Table III: Mean + SD, T Values \& p Values Between Different Grades of PEM and Control for Serum AST Levels

\begin{tabular}{|l|c|c|c|c|}
\hline Groups & $\begin{array}{c}\text { Serum AST } \\
\text { mean } \pm \text { SD }\end{array}$ & d.f. & 't' values & 'p' values \\
\hline Grade I & $42.8 \pm 11.06$ & 61 & 6.94 & $<0.001$ \\
\hline Grade II & $31.47 \pm 8.32$ & 58 & 2.70 & $<0.01$ \\
\hline Grade III & $35.00 \pm 10.86$ & 51 & 3.54 & $<0.01$ \\
\hline Control & $25.42 \pm 8.77$ & - & - & - \\
\hline
\end{tabular}

Fig. 3: Grades of PEM for Serum ALT and AST

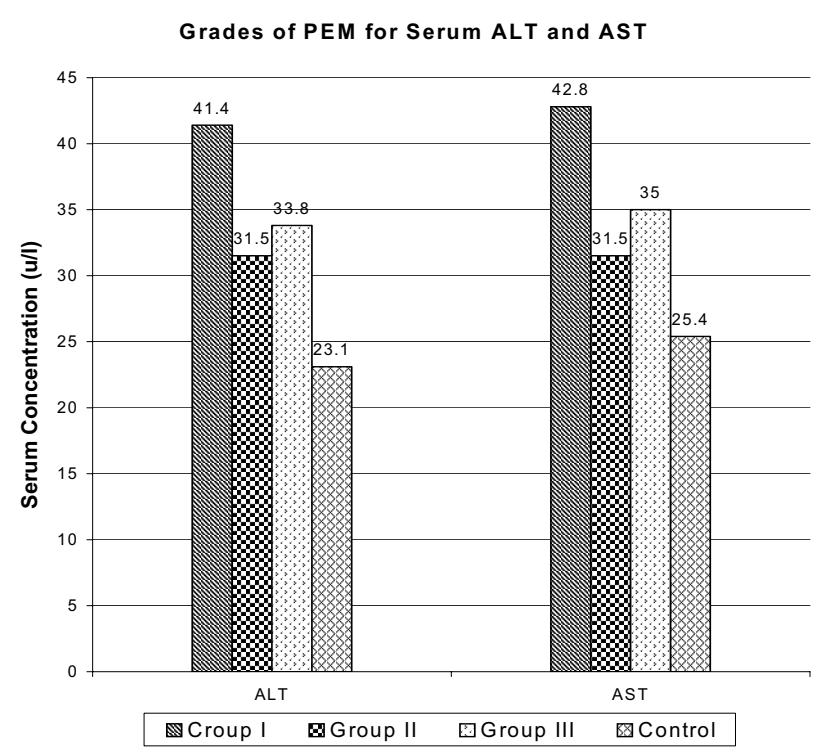


Table IV: 'T'Values \& 'p' Values Between Different Grades of PEM for Serum ALT Levels.

\begin{tabular}{|l|c|c|c|}
\hline Grade of PEM & d.f. & 't' values & 'p' values \\
\hline Grade I Vs Grade II & 69 & 3.47 & $<0.001$ \\
\hline Grade II Vs Grade III & 59 & 0.74 & $>0.10$ \\
\hline Grade I Vs Grade III & 62 & 2.35 & $<0.05$ \\
\hline
\end{tabular}

Table V: 'T' Values \& 'p' Values Between Different Grades Of PEM for Serum AST Levels.

\begin{tabular}{|l|c|c|c|}
\hline Grade of PEM & d.f. & 't' values & 'p' values \\
\hline Grade I Vs Grade II & 69 & 4.90 & $<0.01$ \\
\hline Grade II Vs Grade III & 59 & 1.39 & $>0.10$ \\
\hline Grade I Vs Grade III & 62 & 2.81 & $<0.01$ \\
\hline
\end{tabular}

It was observed that $19(50.0 \%)$ cases of Grade I PEM, $6(17.6 \%)$ of Grade II and 7 (25.9\%) of Grade III PEM had increased level of ALT. The rise was also seen in case of AST. $23(62.2 \%)$ of Grade I PEM, $8(23.5 \%)$ Grade II PEM and $7(25.9 \%)$ Grade III PEM showed rise in the level of AST. (Table VI)

Table VI: Rise of ALT and AST in Percentage

\begin{tabular}{|l|c|c|c|c|}
\hline $\begin{array}{l}\text { Grade of } \\
\text { PEM }\end{array}$ & $\begin{array}{c}\text { No. of } \\
\text { cases with } \\
\text { increased } \\
\text { ALT }\end{array}$ & $\begin{array}{c}\text { \% of } \\
\text { increased } \\
\text { ALT }\end{array}$ & $\begin{array}{c}\text { No. of } \\
\text { cases with } \\
\text { increased } \\
\text { AST }\end{array}$ & $\begin{array}{c}\% \text { of } \\
\text { increased } \\
\text { AST }\end{array}$ \\
\hline $\begin{array}{l}\text { Grade I } \\
(\mathrm{n}=37)\end{array}$ & 19 & $50.1 \%$ & 23 & $62.2 \%$ \\
\hline $\begin{array}{l}\text { Grade II } \\
(\mathrm{n}=34)\end{array}$ & 6 & $17.64 \%$ & 8 & $23.52 \%$ \\
\hline $\begin{array}{l}\text { Grade III } \\
(\mathrm{n}=27)\end{array}$ & 7 & $25.92 \%$ & 7 & $25.92 \%$ \\
\hline
\end{tabular}

Fig. 4 : Rise of ALT and AST in Percentage

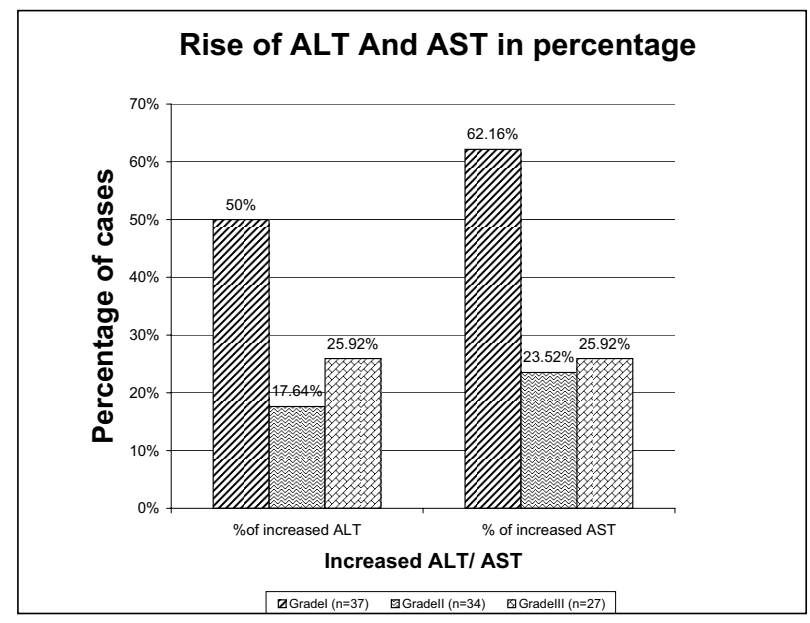

\section{Alkaline Phosphatase}

It was observed that ALP level declined with increasing severity of PEM, shown in Fig 5 below.

Table VII: Mean + SD, T Values \& P Values between Different Grades of PEM and Control for Serum ALP Levels

\begin{tabular}{|l|c|c|c|c|}
\hline Groups & $\begin{array}{c}\text { serumALP } \\
\text { mean } \pm \text { SD }\end{array}$ & d.f & 't' value & 'p' value \\
\hline Grade I & $403.40 \pm 100.76$ & 61 & 16.47 & $<0.001$ \\
\hline Grade II & $294.23 \pm 50.40$ & 58 & 22.88 & $<0.001$ \\
\hline Grade III & $221.26 \pm 94.09$ & 51 & 21.94 & $<0.001$ \\
\hline Control & $894.5 \pm 126.28$ & -- & ---- & ---- \\
\hline
\end{tabular}

Fig.5: Grades of PEM for Serum ALP Level

Grades of PEM for serum ALP Levels

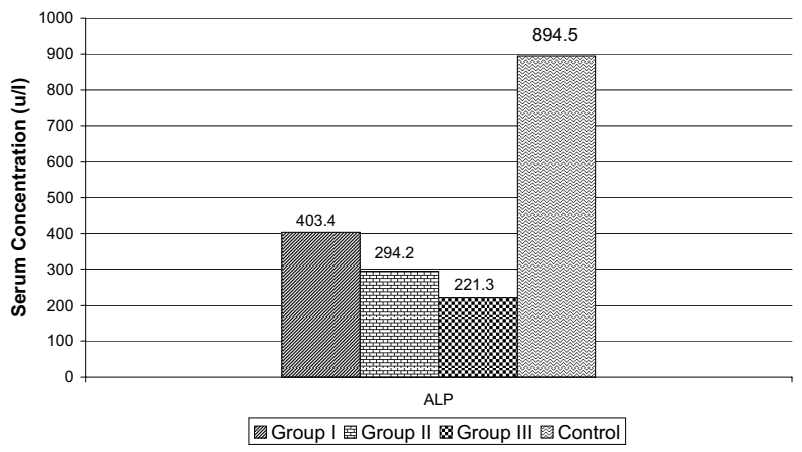

The mean values $(+\mathrm{SD})$ for serum ALP in Grade I, Grade II, and Grade III PEM were 403.4+ 100.76, 294.23 + 50.40, and $221.26+94.09 \mathrm{U} / \mathrm{L}$, respectively which was significantly lower than control $(894.5+126.28 \mathrm{U} / \mathrm{L})$, shown in table VII. The values decreased with increasing grades of PEM, hence lowest in case with Grade III PEM. The decrease in ALP was significant in all Grades of PEM with 'p' values $<0.001$.

\section{Discussion}

In recent years there is an increasing tendency to translate fundamental enzyme knowledge into clinical tools for the definition, study, diagnosis and treatment of disease 5. Present study was designed to determine the levels of ALT, AST, and ALP to compare the status of these parameters with those suffering from different grades of malnutrition and those of control. The possible correlation between serum levels of these parameters within the different grades of malnutrition was also observed. In this study a total of 124 subjects were selected of which 26 were age and sex matched healthy control. Different grades of PEM cases were selected according to classifications by Gomez et al. (1986). This classification expresses actual body weight into the percentage of the expected weight. Children suffering from systemic disease except for PEM and its minor association like ARI and diarrhoea were taken as exclusion criteria. Among the study group 37\% were Grade I PEM, 35\% Grade II and 28\% Grade III PEM. 
Alanine Aminotransferase and Aspartate Aminotransferase (AST): In this study serum ALT level was higher than control in 50\% of Grade I PEM, $17.64 \%$ Grade II PEM and $25.92 \%$ of Grade III PEM. Similarly serum AST level in $62.16 \%$ of Grade I PEM, 23.52\%of Grade II and $25.92 \%$ of Grade III PEM were higher than control. Similar results were observed by other workers ${ }^{6-11}$. They found that $20-70 \%$ cases of PEM serum ALT and AST level were raised. They suggested that the exaggerated tissue breakdown in PEM is associated with conversion of most pyruvate into alanine by transamination in order to transport ammonia out of tissue breakdown ${ }^{12}$. The increase in levels of serum ALT (mean $+\mathrm{SD}=41.40+13.25$ ) and $\mathrm{AST}$ (mean $+\mathrm{SD}=42.80+$ 11.06) was maximum in Grade I PEM, which is consistent with other studies ${ }^{13,14}$. This probably indicates maximum tissue breakdown in early stages of PEM. They also observed that the increase in serum ALT and AST in Grade II PEM was significantly higher than Grade III PEM.

In the present study, however similar results were not observed. Grade III PEM showed higher enzyme levels, that are ALT mean 33.77U/L and AST mean $31.47 \mathrm{U} / \mathrm{L}$. The reason why this difference occurred is not clearly understood. But present study shows that all Grades of PEM are associated with alteration in levels of serum ALT and AST. The enzyme levels both ALT and AST are higher than control. This reflects an effort on the part of the body to maintain homeostasis through protein synthesis from tissue breakdown and amino acid metabolism. Since total muscle mass is considered greater than liver mass the total loss from muscle is much greater than the total loss from liver ${ }^{15}$. In the pattern of enzyme change found all grades of PEM showed higher rise of AST than ALT. Mean AST in U/L for grade I, II and III PEM 42.8, 31.47 and 35.00 and ALT level in U/L were $41.40,31.53$ and 33.77 respectively. Endozien ${ }^{16}$ also observed this in 1961.

Infectious hepatitis, acute homologous serum hepatitis are associated with AST values up to 2500 and ALT activity up to 3600 spectrophotometric units. The comparatively smaller increase in activities of serum ALT And AST in case of PEM may be related to the decrease of liver cell mass and possibly also to low concentration of liver cell enzymes ${ }^{16}$. In liver disease, level of ALT usually exceeds as that of AST activity ${ }^{17}$. But in PEM it is seen that level of AST has exceeded the ALT activity. Therefore in absence of clinical liver disorder the increased serum AST and ALT in this study is possibly due to tissue breakdown.

Alkaline Phosphatase: Serum alkaline phosphatase level in all grades of PEM in this study was significantly lower than controls. The values in Grade II PEM (mean 294.28 U/L) and Grade III PEM (mean221.6U/L) was significantly lower than Grade I PEM(mean4033.40U/L). Again the value was significantly $(p<0.001)$ lower in grade III PEM than in Grade II PEM. Low serum values of ALP in PEM have also been reported by other workers ${ }^{18-21}$. Lowering of serum values of ALP could be explained on the basis of generalized protein deficiency leading to impaired synthesis. Failure of bone growth may also contribute to the lowering ALP value ${ }^{22}$. The pattern of reduction of serum ALP levels in different grades of PEM in this study shows that impairment of protein synthesis is maximum in severe PEM (Grade III) and also it is a progressive process corresponding to the loss of body weight. In Sri Lanka, Jaye sekera et al.(1995)found, low values for ALP.

At Kampala (Uganda) Dean \& Schwartz (1953) found, serum ALP to be low to normal even with associated rickets in PEM. Metwalli et al.(1978) stated that ALP activity increases in protein depleted animals and is suggestive of increased enzyme protein synthesis. Alkaline phosphatase, a zinc dependent enzyme decreases in $\mathrm{Zn}++$ deficiency state, which occurs in $\mathrm{PEM}^{23}$. This change in the activity of serum enzyme is related to the protein intake. Also it has been suggested that the decrease in a ALP activity may be related to bone growth failure but direct proof of this is not available.

The present study shows rise in the transaminases (ALT\&AST) levels in all Grades of PEM. The rise being highest in Grade I PEM. The levels of ALP, decreased in direct proportion to severity of PEM. More comprehensive study with larger number of subjects may provide better information in this regard.

\section{Conclusion}

It can be concluded that serum enzymes (ALT, AST, and ALP) changed in PEM and these varied according to severity. These results may help physician in early detection of PEM before the clinical features are manifested and it may also help to detect the severity. A definite range of different enzyme levels may be defined as a supportive tool to detect different grades of PEM, mainly mild and moderate PEM, which form the major bulk of the problem.

\section{References}

1. Ibrahim S.A., Eltom A.M., Rahaman A.M. et. al. East African Medical Journal, 1994;2;77-82.

2. Bengoa J.M., The Problem of Malnutrition, WHO Chron 1974; 28;3-7.

3. Kumari R., Rao Y.N., Talukdar B. et.al., Serum Enzyme Abnormalities in Protein Energy Malnutrition, Indian Pedtr 1993;30:469-473.

4. Barltrop D. and Sandhu B.K. Marasmus Post Gr. Medical Journal 1985;61:915-923.

5. Wrobleski F. Increasing Clinical Significance of Alterations in Enzymes of body Fluids. Tnter Medical $1959 ; 50$ (1); 62-92.

6. McLean AEM. Heptic Failure in Malnutrition. Lancet 1962,2; 1292-1294.

7. Mc Farlane. H. Ogbeide MI, Reddy S. et.al., Biochemical Assessment of Protein Calorie Malnutrition, Lancet 1969, 1; 392-395.

8. Bola D.A., Sifo J. O., Bolodeoku. Serum Aspartate and Alanine Amino Transferase Activities in Protein Energy Malnutrition. Enzyme 1982, 28: 300-304.

9. Kumari R., Rao Y.N., Talukdar B. et.al., Serum Enzyme Abnormalities in Protein Energy Malnutrition, Indian Pedtr 1993;30:469-473. 
10. Mc Farlane. H. Ogbeide MI, Reddy S. et.al., Biochemical Assessment of Protein Calorie Malnutrition, Lancet 1969,1; 392-395.

11. Rao A., Cherian A., Onuora C.U. Suvarnabai P.C. Serum Amonitransferases and r-glutamyl transferase in Protein Energy Malnutrition. Trop Geogr Med. 1985, 37:11-14.

12. Dreyfus J. Shapira G., Shapira F., Serum Enzymes in the Physiopathology of Muscle. Ann NY Acad Sci 1958, 75: 235-249.

13. Kumari R., Rao Y.N., Talukdar B. et.al., Serum Enzyme Abnormalities in Protein Energy Malnutrition, Indian Pedtr 1993;30:469-473.

14. Rao A., Cherian A., Onuora C.U. Suvarnabai P.C. Serum Amonitransferases and $\gamma$-glutamyl transferase in Protein Energy Malnutrition. Trop Geogr Med. 1985, 37:11-14

15. Waterlow J.C. The Protein Content of Liver and Muscle as a Measure of Protein Deficiency in Human Subjects. Indian Medical Journal, 1956, 5:167.

16. Endozein J.C. Enzymes in Serum in Kwashiokar. Pediatrics 1961, 27: 325-333.
17. Wrobleski F. Increasing Clinical Significance of Alterations in Enzymes of body Fluids. Tnter Medical 1959;50 (1); 62-92.

18. Dean RFA, Schwartz R., Serum Chemistry in Uncomplicated Kwashiorkor. Brit.J.Nutr 1953;7:131147.

19. Schwartz R. Alkaline Phosphatase Activity in Kwashiorkor, Journal Clin Path 1956, 9:333

20. Singh R.S, Agrawal S.P. \& Dikshit S.K., Serum Enzymes in Nutritional Muscular Wasting. Ind J. Pedtr. 1972, 39:299: 383-388.

21. Reddy V., Srikantia SG. Serum Alkaline Phosphatase in Malnourished Children with Rickets. J. Pedtr 1967:8:126-129

22. Shrimshaw, N.S. \& Behar, M., Protein Malnutrition in Young Children, Science, 1961, 133:2039.

23. Forfar \& Arneil. Text Book of Pediatrics 5th Edition 1998; Campbell A.G.M. \& McIntosh N, BPC Wheatons Ltd; Exeter; 457. 